\section{Genetically modified foods face rigorous safety evaluation}

Sir - The Commentary by Erik Millstone et al. ${ }^{1}$ on the role of substantial equivalence in the safety evaluation of genetically modified (GM) food draws attention to important issues, but it gives an inaccurate and misleading account of the work of regulatory committees and the current role of substantial equivalence in safety evaluation.

The authors imply that regulatory committees depend on substantial equivalence as the sole basis for the safety evaluation of GM foods. They suggest that only chemical tests are used, and that biological, toxicological and immunological methods are ignored. This seriously misrepresents the work of independent expert committees that give careful and wide-ranging consideration to the safety of GM foods on a case-by-case basis, and do not rely solely on substantial equivalence.

From the standpoint of safety evaluation, substantial equivalence is a useful tool to address a major limitation in traditional toxicology approaches to whole GM foods. The feeding of excess quantities of individual chemical components to experimental animals can easily be distinguished from overall nutrition. This approach can be used to set acceptable daily intakes for nonnutrient chemical components of the diet. In contrast, whole GM foods are complex, contribute to nutrition and are limited in the quantity that can be consumed. So the interpretation of data from animal feeding experiments is far from simple.

The safety evaluation of GM food is far more rigorous than is applied to its conventional counterpart, and aims to establish that the accepted safety of the conventional counterpart has not been compromised. In Europe, the safety evaluation of GM foods is covered by European Commission (EC) regulation 258/97. The work of the UK Advisory Committee on Novel Foods and Processes (ACNFP) now falls within its framework ${ }^{2}$. According to the EC, "substantial equivalence is not a safety or nutritional assessment in itself, but an approach to compare a potential new food with its conventional counterpart" ${ }^{\prime \prime}$.

In most instances GM technology is applied to a crop plant to introduce a new trait, so the GM plant cannot be substantially equivalent to its conventional parent. An example that illustrates the fact that much more than substantial equivalence is involved is the safety evaluation of GM soya ${ }^{4}$. Safety evaluation focused on four issues: intentional changes; unintentional changes; stability; and gene transfer. GM soya contains a single introduced bacterial gene that confers tolerance to the herbicide glyphosate. This gene produces a glyphosate-insensitive homologue of the natural plant enzyme, 5-enolpyruvylshikimate-3-phosphate synthase (EPSPS), that is involved in aromatic amino-acid biosynthesis. Detailed molecular analysis authenticated the genetic modification and demonstrated that it was stable through several generations of conventional plant breeding. An acute toxicity study in mice showed that the introduced EPSPS protein was non-toxic, and it was demonstrated that this protein is rapidly degraded under conditions encountered following consumption. Furthermore, the conventional processing of soya was shown to destroy the protein. So EPSPS, which in any event is inactivated in marketed GM food, is safe.

The possibility that unintended changes had taken place was evaluated by comparing compositional data and nutritional studies for GM and conventional soya. It is known that unprocessed soya beans can cause food allergy, and the levels of known allergenic proteins were unchanged in GM soya. The possibility of gene transfer from GM soya was eliminated by DNA degradation during processing. On the basis of this evaluation, ACNFP concluded that GM soya was as safe as its conventional counterpart.

Substantial equivalence has recently been re-evaluated by the Organization for Economic Cooperation and Development ${ }^{5}$. A useful aspect of this evaluation is the recommendation of a consensus on appropriate components for compositional analysis so as to standardize safety evaluation. Key nutrients and known toxins, antinutrients and allergens would be included in this consensus.

The expression of previously unknown toxins, antinutrients or allergens in GM foods so as to cause previously unrecognized harm is unlikely, given that conventional foods have been subject to massive changes in genetic make-up by established plant-breeding methods. The use of chemical fingerprinting, messenger RNA analysis, DNA arrays and proteomics to investigate unintended effects are recognized possibilities for the future, but the practical value of these techniques has not been established. Changes to gene expression and to the levels of individual proteins and metabolites are a normal feature of plant development and response to environmental change. Any such detailed holistic analysis needs to be considered in the context of a dynamic situation in which flux in gene expression is the norm.

\section{J. Gasson}

Institute of Food Research, Norwich Research Park, Colney, Norwich NR4 7UA,UK

1. Millstone, E., Brunner, E. \& Mayer, S. Nature 401, 525-526 (1999). 2. ACNFP Annual Report 19973-6 (1997).
3. Official Journal of the European Communities L253, 16/09/1997, 1-36 (1997). (http://europa.eu.int/eur-lex/en/lif/dat/1997/ en_397X0618)

4. ACNFP Annual Report 199459-65 (1994).

5. http://www.oecd.org/ehs/food

\section{Bureaucracy blights Japan's safety record}

Sir - Your editorial, "Perils of inadequacies in safety regulation", hits on a universal problem in Japan (Nature 401, $513 ; 1999)$. Besides the nuclear accident and blood products scandal you refer to, there are numerous other examples that testify to the absence of proper management of science and technology in Japan. Large quantities of dioxins are still emitted from refuse incinerators despite global concerns, for example.

Why is Japan unable to control these serious problems? The main reason lies in the machinery of national government, in which the system of authority is administered by bureaucrats. Government offices jettison their veteran officials into high positions in public corporations and related industries to maintain their pyramidal stratification based on a system of seniority. According to the prime minister's office, of 6,843 public corporations under the jurisdiction of the national government, 2,470 had 6,903 ex-bureaucrats as directors in 1997. But this is only the tip of the iceberg. There are many other corporations under the jurisdiction of local government, and numerous private enterprises, that accept retired bureaucrats as executives. The nuclear and pharmaceutical industries are no exception. This practice has meant that respect for irresponsible figures in authority has been cultivated and protected.

The bureaucrats have excellent administrative ability, and industries find it valuable to make connections with them. But these bureaucrats lack expertise in management of unexpected disasters, such as the Tokai nuclear accident. To make matters worse, they lack the expertise needed to regulate the industries for which they are responsible.

Unless this problem is resolved, it will be impossible to establish in Japan effective regulatory bodies, similar to the US Food and Drug Administration. The bureaucrats have a strong hold on major industries. They know that, if new regulatory bodies are established, their grip on industry will loosen irreparably. And industrialists feel they may not survive unless favoured by authority - many companies have made lucrative profits under the status quo.

The first step to resolve this problem may be international acknowledgement of the lack of expertise in safety regulation among Japanese bureaucrats. Responsibility for the management of science and technology 
should not be limited to one country. We have more powerful science and technology than ever before, and this does not allow any margin for errors. The Tokai accident and other scandals sound a warning that Japan, which should have high levels of control of science and technology, has made light of safety regulation.

\section{Kazuo Inoue}

Towa Clinic, 468 Showa, Towa, Hata, Kochi 786-0511, Japan

\section{Challenge for global e-journal project}

\section{Sir - The proposed repository for} research reports, PubMed Central ${ }^{1}$, is rapidly decomposing itself. As I cautioned in Nature ${ }^{2}$, the US National Institutes of Health (NIH), which developed the proposal, has failed to confront three key issues: funding, lack of expertise, and consensus building. The latest silliness involves an alliance between PubMed Central and the Community of Science, to fund the peer-review function of the repository. This is yet another bleak development in the brief history of this initiative.

NIH director Harold Varmus proposed this project in a particular setting. Workers from many disciplines, including library and information sciences, computer science, clinical medicine, and the biological sciences, had been struggling for several years to develop the tools and procedures needed to produce an online archive of bioscience research reports. When Varmus and the NIH were initially confronted with an avalanche of negative comments, they quickly attempted to revise the proposal. But each succeeding incarnation of the PubMed Central scheme was ever more insipid. Let us remember the philosophy and purpose that have driven this idea in the larger communities of research, information and science: free, unfettered, global access to a permanent, online archive of research reports in the biological and medical sciences.

For-profit publishers have already created many commercial models that are attempting to mimic such a repository, with generally poor results. The typical electronic model is worse than the traditional paper journal. It is more difficult to navigate, resides behind cost barriers that exclude vast numbers of researchers, and conforms to no archival standards. Varmus and the NIH have done nothing to improve this. In fact, the PubMed Central initiative has been a distraction from the concrete steps that are required to ensure funding, access and continuity for such a repository. Canada has put thought, time and funding behind a brilliant national initiative to create what PubMed Central might become.

Last month, a meeting was held in Santa $\mathrm{Fe}$, New Mexico, to discuss and promote the development of standards for what is being called a universal preprint service. This is an important step in the right direction, and draws on the necessary interdisciplinary expertise. The meeting brought together representatives of the American Physical Society, the Council on Library and Information Resources, the Library of Congress, Los Alamos National Laboratory, and various US and overseas universities, among others. The group plans to include as many perspectives as possible, but it needs support (see http://vole.lanl. gov/ups/ups.htm). This is an opportunity for the NIH to get serious or get out.

\section{Lance Sultzbaugh}

Elan Pharmaceuticals, 3760 Haven Avenue,

Menlo Park, California 94025, USA

1. Macilwain, C. Nature 401, 516 (1999).

2. Sultzbaugh, L. Nature 400, 207 (1999).

\section{How the Church moves with the times}

Sir - I have only one quibble with Hugh Montefiore's excellent review of A. N. Wilson's book, God's Funeral (Nature 401, 211-212; 1999). Montefiore mentions that, in the Roman Catholic Church, "attempts to fit the ancient doctrines of the Church into modern dress were savagely suppressed as late as 1907”. This description of the anti-Modernist party that held sway in the turn-of-the-century Church is oversimplified. Unfortunately, it reinforces the misconception that the Church is a monolithic entity, which unilaterally changed its thinking about scripture and science at a particular time, rather late in the game.

Church officials in the past may have looked with great suspicion on the writings of, say, Teilhard de Chardin; but this same Church did, after all, produce a Teilhard. Even earlier, John Henry Newman was made a cardinal notwithstanding his liberal views. Prominent theologians in every era, going back to the most ancient Church fathers, argued cogently and consistently against a literalist interpretation of scripture. On the other hand, I'm sure you could find closet creationists in the Catholic Church today.

To take any one 'official' theological position in isolation can give an erroneous picture of the more general outlook and culture within the Church. The Church, like science, has always been a community of lively debate and evolving understanding.

Just as religion in the nineteenth century was forced to "come to terms with scientific realities", so science and technology in the twenty-first century will proceed at its own peril if it does not come to terms with the ethical and cultural realities of world religions. To do so, an accurate understanding of what religion believes, and how it reaches those beliefs, is essential.

\section{Guy Consolmagno}

Vatican Observatory, V-00120, Vatican City State

\section{Unfair exchange}

Sir-I was delighted to see that there is at last a new edition ${ }^{1}$ of Silvanus P. Thompson's beautiful classic Calculus Made Easy, first published in 1910. I bought this book as an undergraduate and have been recommending it ever since. But now it has been thoroughly modernized.

In the section "On different degrees of smallness", for example, Thompson wrote "Again, think of a farthing compared with a sovereign", but the revised edition reads "Again, think of a hundred dollars compared with a penny". And later, "Now if Mr Millionaire received during next week $\mathfrak{E} 1,000$, the secretary would receive $\mathfrak{E} 10$ and the boy two shillings" has been clarified by transmutation to "Now if Mr Millionaire received during next week $\$ 1,000$, the secretary would receive $\$ 10$ and the boy 1 dime".

Some of my carping colleagues have suggested that such changes amount to cultural imperialism. What nonsense! Although it is true that most of the British students for whom the book was originally written are unlikely to know what a dime is worth, this is easily remedied by adding an extra lecture to the course, followed by a test to make sure they know the values of nickels, dimes and quarters. This fine modernization has been properly acknowledged by the fact that the biographical notes of Thompson's editor, Martin Gardner, are longer than those of Thompson.

I hope that we may look forward soon to a properly modernized edition of Charles Dickens' works from Macmillan, in which Mr Micawber will say "Annual income $\$ 32$, annual expenditure $\$ 31.96$, result happiness. Annual income $\$ 32$, annual expenditure \$32.04, result misery”. And Oliver Goldsmith's Deserted Village could be brought up to date as "A man who was to all the country dear, And passing rich on sixty-four dollars a year".

Computers should allow easy modernization of graphics. The price of the Mad Hatter's hat could be changed from an anachronistic $10 / 6 \mathrm{~d}$ to an up to date 84 cents. Sadly, though, the modernization of The Merchant of Venice could pose insuperable problems, given the difficulty of determining the exchange rate of the ducat. David Colquhoun

Department of Pharmacology, University College London, Gower Street, London WC1E 6BT, UK

1. Thompson, S. P. \& Gardner, M. Calculus Made Easy

(Macmillan, Basingstoke, 1998). 